\title{
Byelorussian Chronicle 1974
}

\section{EVENTS IN BYELORUSSIA}

The well-known Byelorussian writer Vasil Bykaŭ was awarded the Soviet Lenin State prize in literature for his novels Abielisk and Dažyć $d a$ śvitańnia. He was also awarded ihe Order of the Red Flag to mark his 50 th birthday.

The restoration of the 13 th century keep in Kamianiec in Western Byelorussia known as 'Biełaja vieža' (White Tower) has been completed. It now houses a local historical and ethnographical museum.

A monument to Francis Skaryna was unveiled on 9 August in Połack, the native city of the firsi Byelorussian printer. The designers of the monument were sculptors A. Hlebaŭ, I. Hlebaŭ, A. Zaśpicki and 'the architect U. Marokin.

\section{*}

The city of Viciebsk celebrated the 1000th anniversary of its first mention in the chronicles. The Soviet Postal service issued a special stamp to commemorate the occasion.

A Poetry festival took place on 22 September in Mikałajeǔščyna, the birthplace of Jakub Kołas.

The Janka Kupała State Prize in literature for 1974 was awarded to the playwright Kandrat Krapiva for his comedy Brama nieŭmiručaści. The Jakub Kołas prize went to another playwright, Andrej Makajonak, for his plays Trybunat and Tabletku pad jazyk. Aleś Jakimovič won the state prize for the best book for children for his historical novel Kastuś Kalinoŭski. The music prize went 'to Ryhor Syrma for his publication Biełaruskija narodnyja pieśni, and the art prize was won by the sculptors Anatol Anikiejčyk, Leŭ Humileŭski and Andrej Zaśpicki for their Janka Kupała memorial in Minsk.
The highesc Soviet award for the most artistically produced book was awarded to the Byelorussian publishing house 'Bielarus' for the book Pieśnia pra zubra (artist Arlen Kaškurevič), which is a 'translation by $\mathrm{J}$. Siemiažon of the poem Carmen de natura, feritate ac venatione bizontis by the early 16th cen'tury Byelorussian Latin poet Nicholas Husoŭski.

A new Polytechnical Institute was opened on 1 January in one of Byelorussia's new cities, Novapołack, centre of the growing oil industry.

A conference on the 'Problem of specific characteristics of literary genres' was held in May in Mahiloŭ. Also in May in Minsk there was a conference enti'tled 'The prose genres of the folklore of the peoples of the USSR'. In August another conference on the subject of 'Certain regular features in the development of Byelorussian literature' took place.

Charoški is the name of a small village in the Mahiloŭ province in Eastern Byelorussia. It became famous a few years ago, when its inhabitants, at the national folk ar'i festival in Minsk, charmed everybody with the performance of old 'traditional songs and dances which have been either long forgotten or completely unknown in other parts of Byelorussia. Now the village has given its name to the new dance ensemble in Minsk, whose aim is to revive traditional Byelorussian folk dances, putting them in a modern choreographical setting.

$$
\text { * }
$$

Byelorussian television produced a very succesful play enti'tled I śmiech $i$ biada (director J. Saba) based on short stories by Jakub Kolas. Another succesful television production was the play Tartak based on the novel of the same name by Ivan Ptašnikaŭ. 
The Mahiloŭ Regional Theatre of Comedy and Drama in Babrujsk staged in March the premiere of a new play by A. Pietrašlkievič, Złydzień. The premiere of Pietraškievič's other play, Tryvoha, was staged by the Jakub Kolas Theatre in Viciebsk.

\section{*}

A festival 'Golden autumn' was held in Minsk with the participation of variety artists from Jugoslavia,

\section{EVENTS ABROAD}

Byelorussian writers and poets living in Poland have their own organization called 'Biełavieža'. They usually publish their new works in the monthly literary supplement to the weekly Niva, and from time to time produce literary almanacs. There are also a number of publications of individual authors. Some of the best known among them, such as the poets Aleś Barski and Viktar Šved and 'che prose writer Sakrat Janovič, have had their works translated into Polish and other languages. Of considerable incerest are the attempts by some younger poets, such as Zosia Sačko, Ivan and Piatro Kirziuk, to write in their native Byelorussian dialect of the easi Białystok region.

$$
\text { * }
$$

March 26 was 'Byelorussian day' at the Soviet Industrial Exhibition in Düsseldorf. Among Byelorussian industrial products shown on that day were the EC-1020 computer, the tractor 'Biełaruś' and the gian'i 40-ton tip-up lorry. The highlights of the cultural programme consisted of performances by 'the Byelorussian State Philharmonic orchestra and the famous 'pop' group 'Pieśniary'.

The Byelorussian pavilion 'Minsk' enjoyed great popularity among visitors to the Toronto ethnic festival 'Caravan-1974' which was held on 27 June - 1 July. There was a rich programme of Byelorussian songs and dances, an exhibition of Byelorussian books, and visitors were able to sample Byelorussian national dishes. The pavilion was organised by members of the Byelorussian Youth Association of Canada and the USA.

$$
*
$$

France, Poland, Argentina, Hungary, East Germany and other countries.

Prof. Joseph Żynovič, director of the Byelorussian State Folk Insirument orchestra and creator of the well-known cymbaly ensemble, died on 13 January, aged 67. Uładzimir Stelmach, 'the well-known actor, playwright and stage director died on January 27. He was also 67 years old.

The 11th Encounter of Byelorussians of North America was held on 31 August -1 September at the Byelorussian holiday resort 'Połack' near Cleveland.

A course of lectures entitled 'Byelorussian Cultural Heritage in America' Ivas held on 17-24 April in the New York City College. The speakers were Dr. V. Kipiel (New York Public Library) and Dr. J. Zaprudnik (Queens College, New York City University).

$*$

On 26 November Dr. J. Zaprudnik read a paper entitled 'Byelorussian Nationalism and the Territory of Byelorussia' at Rutgers University.

The following papers were read during the 9th Lecture Course on Byelorussian Culture, organised by the Anglo-Byelorussian Society in London for the academic year 197475: 'A 17th century Slavonic and Latin manuscript of the Pontifical Liturgy of St. John Chrysostom' (Rt. Rev. C. Sipovič); 'Anton Navina Euckievič (1884-1946) and the origins of the Byelorussian New Testament and Psalms' (G. Picarda); 'Byelorussian early printed books in Western libraries' (A. Nadson); 'Recent changes in norms of literary Byelorussian' (P. Mayo); 'Where on earth do they come from? - Ethnogenesis of the Byelorussian people' (J. Dingley); 'Aspects of the Tartar settlements in Byelorussia' (S. Akiner). 